\title{
Jurist-Diction
}

Volume 2 No. 6, November 2019

Histori artikel: Submit 1 Oktober 2019; Diterima 23 Oktober 2019; Diterbitkan online 1 November 2019.

\section{Problematika Hukum Pada Peer To Peer Lending di Indonesia Dalam Perspektif Hukum Persaingan Usaha}

\author{
Cheyzsa Mega Andhini S.P \\ ichacheyzsa@gmail.com \\ Universitas Airlangga
}

\begin{abstract}
E-commerce which is a form of electronic commerce has become a trend in Indonesia lately. Not only trading electronically, but also equipped with Payment Technology (here in after abbreviated as Fintech). Fintech is an innovation in the field of financial services. Fintech in Indonesia has become one of the alternatives in terms of payments based online. Well known as an online credit system called P2P Lending. P2P Lending are based on the law in the Financial Services Authority Regulation Number 77 / POJK.01/2016 concerning Information Technology-Based of Lending and Borrowing Services, as a legal basic for the lending system and borrowing from electronic systems. But, P2P Lending that have sprung up in Indonesia make conventional Banks also offer the same facilities in banks, namely the credit online system. The similarity of facilities between P2P Lending and Credit Online System faces unfairly business competition, because they depend on the same relevant market. Keywords: Fintech; P2P Lending; Credit Online System.
\end{abstract}

\begin{abstract}
Abstrak
E-commerce yang merupakan bentuk perdagangan elektronik menjadi tren dalam perdagangan di Indonesia saat ini. Tidak hanya perdagangan secara elektronik saja melainkan diiringi dengan adanya pembayaran secara elektronik yang kita kenal dengan Financial Technology (Selanjutnya disingkat fintech). Fintech adalah sebuah inovasi di dalam bidang jasa keuangan. Fintech yang bermunculan di Indonesia ini menjadi salah satu alternatif dalam hal pembayaran berbasis online. Salah satu jenisnya adalah sistem kredit secara online yang disebut dengan P2P Lending. P2P Lending secara legal diatur dalam Peraturan Otoritas Jasa Keuangan Nomor 77/ POJK.01/2016 Tentang Layanan Pinjam Meminjam Berbasis Teknologi Informasi, sebagai dasar hukum terkait sistem pinjam meminjam dengan system elektronik. P2P Lending yang bermunculan di Indonesia membuat pihak bank konvensional juga menawarkan fasilitas yang sama pada perbankan yaitu sistem kredit online. Kesamaan fasilitas antara P2P Lending dan Kredit Online Sistem ini menimbulkan persaingan usaha tidak sehat, karena mereka berada pada relevant market yang sama.
\end{abstract}

Kata Kunci: Fintech; P2P Lending; Credit Online System.

\section{Pendahuluan}

Pertumbuhan ekonomi sejalan dengan perkembangan teknologi yang dapat mempengaruhi pola kehidupan masyarakat. Sebagai contoh perdagangan yang sebelumnya dilakukan dengan cara bertatap muka, kini dapat dilakukan dengan cara online. Perubahan pola hidup masyarakat ini yang dinilai lebih efektif dan efisien untuk dikerjakan, karena tidak membutuhkan banyak waktu untuk melakukan aktivitas tersebut. Sama halnya dengan sistem perdagangan, saat 
ini banyak sekali aplikasi perdagangan secara online atau yang biasa disebut perdagangan dengan system elektronik yang ditawarkan. Munculnya system perdagangan secara online dengan system elektronik ini menjadi salah satu contoh pergeseran pola kehidupan masyarakat.

Perdagangan secara online tersebut disebut juga dengan E-commerce. E-commerce merupakan kepanjangan dari Electronic Commerce yang berarti perdagangan online yang dilakukan secara elektronik. ${ }^{1}$ E-commerce juga mempunyai arti perdagangan online dengan system elektronik yang mencakup proses pembelian, penjualan, transfer, atau pertukaran produk, layanan, atau informasi melalui jaringan computer, termasuk Internet. ${ }^{2}$

E-commerce yang merupakan bentuk perdagangan elektronik menjadi tren dalam perdagangan di Indonesia saat ini. Sehingga tidak hanya perdagangan secara elektronik melainkan diiringin dengan adanya pembayaran secara elektronik yang kita kenal dengan Financial Technology (Selanjutnya disingkat fintech). Fintech adalah sebuah inovasi di dalam bidang jasa keuangan. Fintech mempengaruhi kebiasaan transaksi masyarakat menjadi lebih praktis dan efektif. Fintech pun membantu masyarakat untuk lebih mudah mendapatkan akses terhadap produk keuangan dan meningkatkan literasi keuangan. Bank Indonesia mengklarifikasi empat jenis fintech: ${ }^{3}$

1. Crowdfunding dan Peer to Peer Lending, adalah layanan fintech yang berguna sebagai mediasi yang menemukan investor dengan pencari modal, layaknya market place. Crowdfunding (pembiayaan masal atau berbasis patungan) dan peer to peer (Selanjutnya disingkat P2P Lending) ini diawasi oleh Otoritas Jasa Keuangan.Crowdfunding sangat berguna untuk melakukan penggalangan dana seperti untuk mendanai sebuah karya, membantu korban bencana dan lainnya. Munculnya fintech, penggalangan dana dapat dilakukan secara online, sehingga penggalangan akan lebih mudah dan efisien. P2P Lending merupakan sebuah layanan fintech yang sangat membantu masyarakat UMKM sehingga mereka dapat meminjam dana dengan mudah

\footnotetext{
1 Jay M.S, Peran E-Commerce dalam Sektor Ekonomi dan Industri, (Elex Media Komputindo 2001).[24].

2 Abdul Halim Barkatullah, Bisnis E-Commerce (Pustaka Pelajar 2006).[45].

${ }^{3}$ Finansialku, "Inklusi Keuangan dalam P2P Lending", <https://www.finansialku.com/ bank-fintech-p2p-lending-inklusi-keuangan> diakses pada tanggal 12 Maret 2019.
} 
walaupun mereka belum memiliki rekening di bank. Permodalan tentunya merupakan sebuah isu yang sangat signifikan tentunya untuk mengembangkan usaha dan memenuhi kebutuhan finansial masyarakat.

2. Market Aggregator, Pada klasifikasi ini fintech akan berperan sebagai pembanding produk keuangan, dimana fintech tersebut akan mengumpulkan dan mengoleksi data finansial untuk dijadikan referensi oleh pengguna. Klasifikasi ini juga dapat disebut dengan nama comparison site atau financial aggregator. Contohnya, jika seorang konsumen ingin memilih produk Kredit Perumahan Rakyat (Selanjutnya disingkat KPR), platform fintech akan menyesuaikan data finansial pribadi konsumen dan memberikan pilihan produk KPR sesuai dengan data pribadi yang dimasukkan. Pilihan ini akan diberikan sesuai dengan keinginan dan kemampuan finansial serta preferensi konsumen.

3. Risk and Investment Management, konsep yang ditawarkan Fintech dalam klasifikasi ini memiliki fungsi seperti financial planner yang berbentuk digital. Pengguna akan dibantu untuk mendapatkan produk investasi yang paling cocok sesuai dengan preferensi yang diberikan. Selain manajemen risiko dan investasi, pada klasifikasi ini, juga terdapat manajemen aset, dimana Fintech akan membantu operasional sebuah usaha sehingga lebih praktis. Fintech yang bergerak dalam bidang perencanaan keuangan juga tergolong di dalam klasifikasi jenis ini.

4. Payment, Settlement dan Clearing, Jenis Fintech yang tergabung di dalam klasifikasi ini adalah pembayaran (payments) seperti payment gateway dan e-wallet. Klasifikasi ini diawasi oleh BI (Bank Indonesia) karena proses pembayaran ini juga meliputi perputaran uang yang nantinya akan menjadi tanggung jawab Bank Indonesia. Uang elektronik merupakan uang yang dikemas dalam bentuk digital yang mana uang tersebut dapat menjadi alat pembayaran pada umumnya, untuk berbelanja, membayar tagihan dan lainnya hanya dengan melalui sebuah aplikasi.

Fintech yang bermunculan di Indonesia ini menjadi salah satu alternatif dalam hal pembayaran berbasis online. Salah satu jenisnya adalah sistem kredit secara online yang disebut dengan P2P Lending. P2P Lending ini hadir sebagai salah satu contoh jenis dari E-Commers jenis C2C. P2P Lending juga secara legal diatur dalam Peraturan Otoritas Jasa Keuangan Nomor 77/ POJK.01/2016 Tentang Layanan Pinjam Meminjam Berbasis Teknologi Informasi (Selanjutnya disebut sebagaiPOJK 77/ POJK.01/2016) sebagai dasar hukum terkait sistem pinjam meminjamdengansistemelektronik yang biasadisebut Financial technology. P2P Lending yang baru beroperasi 2016 sudah diminati dan mulai banyak perusahaan berbasis PT yang bergabung didalamnya salah satu perusahaan unggulanya adalah PT. Investree, Amarta.co.id, Koinworks, dll. Layanan P2P Lending merupakan 
sebuah perusahaan yang mempertemukan para pemberi pinjaman (investor) dengan para pencari pinjaman (borrower)4. Terdapat 73Layanan P2P Lending yang terdaftar hingga september 2018 dan 67 diantaranya telah mengantongi izin.5

P2P Lending ini hadir ditengah masyarakat sebagai wujud bahwa pengajuan kredit tidak hanya dilakukan apabila seseorang tersebut memiliki rekening pada perbankan, melainkan juga dapat dilakukan oleh seseorang tanpa harus terlebih dahulu memiliki rekening. Penawaran yang diberikan oleh P2P Lending antara lain karena sistem transaksi digital dipandang lebih memberikan kemudahan, kecepatan, kepraktisan karena dapat dilakukan kapan saja dan dimana saja. Selain itu keunggulan dari P2P Lending juga membuat terobosan baru dengan cara melakukan verifikasi nasabah tanpa tatap muka dan tanpa kertas atau paperless yang belum dapat dilakukan oleh Bank Konvensional. Disamping keunggulankeunggulan yang muncul terdapat pula beberapa kelemahan dari bisnis online P2P Lending ini yaitu terkadang masyarakat masih meragukan apakah layanan ini benar dan amanat atau tidak. ${ }^{6}$

Tidak sedikit pelaku usaha yang berpendapat bahwa dengan adanya P2P Lending ini justru akan menimbulkan persaingan usaha terkait kesamaan tugas dengan produk perbankan khususnya dalam pemberian kredit oleh bank yang berbasis online juga. Kekhawatiran tersebut menbuat pihak industri perbankan dan pembayaran yakni industri transfer dana dan pembayaran dalam hal ini adalah bank memprediksi bahwa dalam lima tahun ke depan, mereka dapat kehilangan 28\% pangsa pasar, sementara para bankir mengestimasikan mereka akan kehilangan 24\% pangsa pasar. Sementara responden dari kalangan pengelolaan aset dan kekayaan dan asuransi masing-masing akan kehilangan pangsa pasar sebesar $22 \%$ dan $21 \%{ }^{7}$

\footnotetext{
${ }^{4}$ Investree "Peer to Peer Lending", <www.investree.com>, diakses pada 16 Februari 2019

5 Data Fintech Terdaftar,"Fintech terdaftar", <www.ojk.go.id $>$, diakses pada16 Februari 2019.

${ }^{6}$ Gracia,"Keuntungan dan Kerugian Peer To Peer Lending", www.kompasiana.com/graciamoudyvallentine 7708/5b4daeab5a676f1d490f6d02/peer-to-peer-p2p-lending?page=all diakses pada tanggal 25 Februari 2019.

7 Data Pangsa Pasar Fintech, "Pangsa Pasar", $<$ http://id/en/media-centre/press-release/2016/ indonesian/83--dari-institusi-keuangan-tradisional--khawatir-bisnis-mereka-.html $>$ dikutip pada tanggal 16 Februari 2019.
} 
Untuk mengantisipasi turunya pangsa pasar tersebut pihak bank sendiri juga tidak ingin tertinggal sehingga ada beberapa produk perbankan yang dibuat untuk menyaingi kehadiran P2P Lending. Salah satunya adalah Dana Instant, dari Bank Danamon. Konsepdari Dana Instant hamper sama dengan P2P Lending yakni layanan pinjam meminjam uang berbasis online namun pihak bank menyebut layanan ini sebagai Credit Online System. Credit online system disebut juga sebagai fitur pengajuan kredit secara digital (digital loan). Didalam Credit Online System pihak yang mendapatkan kredit harus dapat menunjukkan prestasi yang lebih tinggi pada kemajuan usahanya itu, atau mendapatkan pemenuhan atas kebutuhannya. Adapun pihak yang memberi kredit secara material dia harus mendapatkan rentabilitas berdasarkan perhitungan yang wajar dari modal yang dijadikan objek kredit. ${ }^{8}$

\section{Relevant Market Produk Sejenis Credit Online System Pada Perbankan}

Relevant market didalam Hukum Persaingan Usaha lazimnya dilihat dari dua perspektif yaitu Pasar Produk dan Pasar Geografi. Pasar produk pada dasarnya adalah pasar yang ditentukan berdasarkan produk yang saling bersubstitusi. Pasar produk dapat dilihat dari perspektif penjual atau perspektif pembeli (demand-side product market). Dari perspektif penjual (suply change flexibiity) pasar produk ditentukan berdasarkan tingkat kemudahan penjual untuk beralih ke pembeli lain. Seperti contoh ketika pembeli menerapkan trading terms yang memberatkan penjual, pembeli dapat memilih untuk berpindah ke pembeli lain yang menerapkan trading terms yang kompetitif. Sedangkan Pasar Geografis adalah ketentuan mengenai batasan, jangkauan dan wilayah dimana substitusi permintaan dan penawaran berada. ${ }^{9}$

Persaingan usaha pada dasarnya diperbolehkan. Hanya saja yang tidak diperbolehkan adalah persaingan usaha yang tidak sehat yang mengarah kepada praktik monopoli. Hal tersebut telah dilarang pula dalam Undang-Undang Nomor 5 tahun 1999 Tentang Larangan Praktik Monopoli Dan Persaingan Usaha Tidak Sehat (Selanjutnya disebut Undang-Undang Nomor 5 Tahun 1999). Persaingan

\footnotetext{
8 Budi Untung, Kredit Perbankan di Indonesia (Andi 2000).[5].

9 Siswanto Arie, Hukum Persaingan Usaha, Ghalia Indonesia (Bogor 2004).[63].
} 
Usaha muncul apabila telah teridentifikasi struktur pasar dan pasar bersangkutanya. Pengertian struktur pasar ada di dalam Undang-Undang Nomor 5 Tahun 1999 Pasal 1 angka 11 yang berbunyi struktur pasar adalah keadaan pasar yang memberikan petunjuk tentang aspek-aspek yang memiliki pengaruh penting terhadap perilaku pelaku usaha dan kinerja pasar, antara lain jumlah penjual dan pembeli, hambatan masuk dan keluar pasar, keragaman produk, sistem distribusi dan penguasaan pasar. Sedangkan definisi pasar bersangkutan diatur dalam Pasal 1 ayat 10 Undang-Undang Nomor 5 Tahun 1999 yaitu pasar yang berkaitan dengan jangkauan atau daerah pasar tertentu oleh pelaku usaha atas barang dan jasa yang sama atau sejenis atau substitusi dari barang dan atau jasa tersebut. Berikut adalah unsure dari Relevant Market atau Pasar bersangkutan:

1. Pasar produk dapat didefinisikan sebagai produk produk-produk pesaingan dari produk tertentu yang ditambah dengan produk lain yang bisa menjadi substitusi dari produk tersebut. Pembatasan pasar bersangkutan berdasarkan produk atau secara obyektif ketika terdapat barang dan atau jasa yang sama atau sejenis, termasuk subsitusinya. Produk yang dapat menjadi substitusi itu adalah produk yang keberadaanya juga membatasi ruang kenaikan harga dari produk tersebut. ${ }^{10}$ Produk yang dapat digantikan atau di substistusi juga terdapat kesamaan dalam hal fungsi atau peruntukan, peggunaan, karakter spesifik, serta perbandingan lainnya. Sehinga dari sisi penawaran, barang substirusi merupakan produk yang sangat potensial yang dapat dihasilkan oleh pelaku usaha yang berpotensi masuk ke dalam pasar yang sama. ${ }^{11}$

2. Pasar geografis penetapan pasar berdasarkan aspek geografis sangat ditentukan oleh ketersediaan produk yang menjadi obyek analisa. Beberapa faktor yang menentukan proses ketersediaan produk tersebut adalah kebijakan perusahaan, biaya transportasi, lamanya perjalanan, tarif dan peraturan-peraturan yang membatasi lalu lintar perdagangan antar kota atau wilayah. Pasar georgafis juga

\footnotetext{
${ }^{10}$ Natasya Ningrum Sirait, Ikhtisar Ketentuan Persaingan Usaha, (Gramedia 2010), [12].

${ }^{11}$ Peraturan KPPU No.3 tahun 2009 tentang Pedoman Pelaksana Pasal 1 ayat 10 No.5 tahun 1999 tentang Pasar Bersangkutan
} 
dapat diidentifikasi dengan melihat wilayah dimana suatu pelaku usaha dapat meningkatkan harganya tanpa menarik masuknya pelaku usaha baru atau tanpa kehilangan konsumen yang signifikan yang juga berpindah ke pelaku usaha lain yang berada dalam wilayah lain yang menyebabkan tidak mampu mendorong terjadinya perpindahan dari konsumsi produk tersebut. ${ }^{12}$

Oleh karena itu untuk dapat menentukan, apakah suatu barang dengan barang yang lain dapat dinyatakan sama atau sejenis atau dapat dinyatakan menjadi subsitusi terhadap barang tertentu, perlu dilihat dari empat aspek, yaitu:

1. Bentuk lahiriah dan sifat barang, petunjuk pertama dalam mengidentifikasi apakah suatu produk satu pasar atau satu produk merupakan produk substitusi adalah dengan melihat bentuk dan sifat fisik suatu barang merupakan secara obyektif. Dikatakan secara objektif, karena produk yang berbeda tersebut dilihat secara fisik apakah bentuk dan sifat barang tersebut sama atau tidak. ${ }^{13}$ Dapat dilihat dari segi bentuk antara P2P Lending dengan produk credit online system mempunyai persamaan yaitu dengan menggunakan platform online dalam pelayananya yang dapat diakses oleh seluruh masyarakat melalui internet. Lalu sifat yang dapat dilihat dari produk ini adalah sifat penggunaan yang gratis dengan atau tanpa dipungut biaya untuk seluruh pihak yang mengaksesnya sehingga kedua produk tersebut baik P2P Lending dengan produk credit online system berada dalam pasar produk dengan kriteria bentuk dan sifat yang sama.

2. Fungsi barang dan jasa, dalam menelaah unsur pasar bersangkutan dalam jenis pasar produk ini mempunyai maksud apakah suatu barang atau produk dengan barang atau produk yang lain dalam hal ini produk atau barang dalam layanan P2P Lending dengan produk perbankan sejenis mempunyai fungsi yang sama bagi konsumen. ${ }^{14}$ Kedua Produk tersebut diketahui memiliki fungsi yang sama pula yaitu sebagai alat untuk mengajukan pembiayaan kredit secara online. Kedua perusahaan terkait bergerak dalam bidang yang sama dengan

\footnotetext{
${ }^{12}$ ibid.

13 Andi Fahmi Lubis, Hukum persaingan usaha teks dan konteks, (KPPU 2017), [242].

${ }^{14}$ ibid. [243].
} 
fungsi yang sama dengan tujuan memenuhi kebutuhan masyarakat yang dan sebagai alat untuk memperoleh dana secara cepat. Proses pembiayaan tersebut dilakukan dengan system paperlessatautanpakertas dimana merupakan salah satu keunggulan adanya P2P Lending dan juga Credit Online System.

3. Harga barang dan jasa, harga suatu barang tertentu bagi konsumen dapat menjadi pengambil keputusan apakah konsumen akan membeli barang tersebut atau tidak. ${ }^{15}$ Oleh karena itu pada pasar produk yang sama atau sejenis dalam hargabiasanya bersaing. Dalam kasus ini penentuan harga dalam layanan P2PLending denganproduk perbankan sejenisini hadir bersamaan dengan jangkauan minimal hargapembiayaan yang sama yaitu berada pada layanan pembiayaan minimal sebesar dua juta rupiah dan maksimal sebesar duamilyar rupiah untuk pembiayaan kreditnya. Dengan kesamaan tersebut pada saat membutuhkan produk yang biasa dibutuhkan tersebut tidak ada di pasar, konsumen tersebut secara otomatis mau beralih kepada produk yang lain.

4. Flexibilitas barang dan jasa, hal demikian ini akan muncul ketika konsumen membutuhkan barang yang sesuai dengan kebutuhanya apabila ia tidak menemukan barang tersebut di tempat A, maka konsumen akan beralih membeli di tempat $\mathrm{B}$ dengan barang yang sama hanya saja dikarenakan barang antara toko A dan B saling menggantikan. Dengan demikian apabila dikaitkan dengan kasus apabila konsumen ingin melakukan pembiayaan pada sistem yang dikelola oleh Investree namun ternyata ada suatu keaadan dimana layanan yang ada didalam Investree mengalami gangguan atau sebaliknya. Maka konsumen dapat melakukan transaksi pada layanan pembiayaan pada sistem Dana Instant.

Persaingan sehat dan kompetitif dapat dihasilkan dari kebijakan pemerintah yang pro kompetisi dan perilaku pelaku usaha yang saling bersaing secara sehat satu sama lain. Tingginya tingkat persaingan antar pelaku usaha dalam suatu pasar atau industri akan mendorong pelaku usaha untuk menghasilkan produk barang atau jasa yang variatif, baik dari segi harga, kualitas, dan inovasi. Kondisi ini

${ }^{15}$ ibid. [244]. 
menguntungkan bagi konsumen karena konsumen dapat memilih beragam produk dengan harga yang bersaing satu sama lain.

Berdasarkan penjabaran mengenai unsur dari pasar produk tersebut antara produk yang diolah oleh P2P Lending yakni Investree dengan produk Credit Online System, dalam hal ini adalah Dana Instant dari Bank Danamon seluruh pembiayaan kredit dalam Dana Instant ini seluruhnya dikelola dan dibiayai langsung oleh Bank Danamon tidak dengan bank mitra lainya. Dari segi pendaftaran dalam layanan bank danamon terkesan lebih kompleks dalam pendaftaran, karena terdapat persyaratan khusus yaitu hanya berlaku bagi nasabah bank danamon yang telah mempunyai tabungan diatas sepuluh juta. Hal ini yang membedakan dengan PT. Investree.

Berdasarkan penjelasan dari unsur-unsur untuk menentukan apakah ada didalam satu pasar bersangkutan yang sama baik itu dalam pasar produk maupun pasar geografis dapat disimpulkan P2P Lending dengan produk Credit Online System terdapat di pasar bersangkutan atau relevant market yang sama. Sejalan dengan pemenuhan semua unsur dari pasar produk yaitu segi bentuk dan sifat, fungsi, harga dan flexibilitas barang semua unsur telah tercukupi. Dilihat dari segi pasar geografisnya pun untuk kedua layanan ini sama yaitu ada dalam pasar geografis yang sama yaitu dalam batas wilayah Indonesia.

\section{Potensi Perilaku Anti Persaingan Usaha Pada Produk Peer To Peer Lending}

Persaingan tidak diperbolehkan apabila mengarah kepada praktik monopoli yang mengakibatkan persaingan usaha yang tidak sehat. Iklim persaingan usaha yang sehat menurut komisioner KPPU Tresna P. Soemardi merupakan Konstitusi Ekonomi. Dikarenakan seluruh kegiatan yang ada didalam persaingan usaha yang sehat mengarah kepada satu tujuan akhirnya itu tujuan dari terbentuknya UndangUndang 5 tahun 1999 tentang larangan praktik monopoli dan persaingan usaha tidak sehat. ${ }^{16}$ Tidak lain telah tercantum di dalam Pasal 3 Undang-Undang Nomor 5 tahun 1999 antara lain:

\footnotetext{
${ }^{16}$ Komisi Pengawas Persaingan Usaha, 'Persaingan Sehat Sebagai Konstitusi Ekonomi', <www.kppu.go.id>, diakses pada tanggal 18 Februari 2019.
} 
a. Untuk menjaga kepentingan umum dan meningkatkan efisiensi ekonomi nasional sebagai salah satu upaya untuk meningkatkan kesehahteraan rakyat;

b. Mewujudkan iklim usaha yang kondusif melalui pengaturan persaingan usaha yang sehat sehingga menjamin adanya kepastian kesempatan berusaha yang sama bagi pelaku usaha besar, pelaku usaha menengah maupun pelaku usaha kecil;

c. Mecegah praktek monopoli dan atau persaingan usaha tidak sehat yang ditimbulkan oleh pelaku usaha;

d. Dan terciptanya efektivitas dan efisiensi dalam kegiatan usaha.

Persaingan usaha yang sehat tidak semata mata berisi penegakan hukum dan kebijakan, tetapi lebih luas lagi persaingan usaha sehat sesungguhnya adalah sebuah nilai yang bersifat universal sebagaimana yang telah digapai oleh semua negara di dunia. ${ }^{17}$ Namun didalam prakteknya sering kali tujuan umum sebuah persaingan usaha menurut Undang-Undang Nomor 5 Tahun 1999 tersebut tidak dijalankan sepenuhnya. Melihat adanya ketimpangan dalam layanan P2P Lending dengan Credit Online System oleh bank yang tidak sejajar ini maka diperkirakan akan muncul potensi tindakan anti persaingan. Untuk mendeteksi hal tersebut makalangkah berikutnya adalah menelaah jenis atau struktur pasar dari kedua layanan tersebut yang sesuai dengan peraturan dalam hukum persaingan usaha. Pada kasus ini yakni antara P2P Lending dengan produk Credit Online System lebih mengarah kepada pasar oligopoli. Pasar Oligopoli mempunyai unsur-unsur sebagai berikut: ${ }^{18}$

1. Terdapat Beberapa Penjual (Few Sellers).

Hanya terdapat beberapa penjual yang ada di pasar. Hal ini menunjukkan bahwa pangsa pasar masing-masing perusahaan di pasar cukup signifikan. Jumlah perusahaan yang lebih sedikit dibanding pasar persaingan sempurna ataupun persaingan monopolistic disebabkan oleh hambatan masuk ke dalam pasar. Penjelasan ini sangat sesuai dengan kenyataan dalam layanan fintech ini bahwa terdapathanya 73 pelaku usaha dalam hal ini adalah perusahaan P2P Lending saja hingga saat ini dan beberapa perusahaan tersebut telah mempunyai pangsa pasar yang cukup signifikan. Ada pula hambatan masuk kedalam pasar ini apabila dikaitkan dengan kegiatan dalam layanan P2P

\footnotetext{
${ }^{17} \mathrm{ibid}$

${ }_{18}$ Andi Fahmi Lubis, Hukum persaingan usaha teks dan konteks,(KPPU 2017). [34]
} 
Lending hambatan masuk tersebut antara lain harus bersaing dengan pelaku usaha lama yang telah memperoleh pangsa pasar yang jauh lebih banyak dan lebih produk unggulanya lebih dikenal oleh masyarakat. Hambatan tersebut antara lain bagaimana pelaku usaha baru tetap bisa bertahan untuk menjalankan bisnisnya tanpa harus takut untuk bersaing. Namun banyak sekali dari perusahaan layanan P2P Lending ini yang tidak mampu bersaing dikarenakan hambatan persaingan yang cukup tinggi sehingga dari 73 perusahan fintech terdaftar hingga saat ini hanya 67 perusahaan saja yang bertahan dan memiliki ijin untuk melakukan kegiatanya. ${ }^{19}$

2. Saling Ketergantungan (Interdependence). Pada struktur pasar persaingan sempurna maupun persaingan monopolistis, keputusan perusahaan atas harga dan kuantitas hanya mempertimbangkan tingkat permintaan di pasar dan biaya produksi yang dikeluarkan. Sementara di pasar oligopoli, keputusan strategis perusahaan sangat ditentukan oleh perilaku strategis perusahaan lain yang ada di pasar. Karena dasar dari kegiatan antar P2P Lending dengan produk Credit Online System adalah sebuah layanan jasa atau service didalam suatu platform E-commerce yang mempunyai tujuan utnuk memberikan kemudahan pembiayaan kredit terhadap masyarakat atau konsumen. Maka sangat jelas antara keputusan perusahaan atas harga dan kuantitas serta keputusan strategis perusahaan sangat bergantung pada pasar. Konsumen yang ikut dalam proses pembiayaan yang dilakukan perusahaanya.

Kekuatan pasar muncul bila ada monopoli dan atau oligopoly dari perusahaan atau produsen tertentu saja. Kekuatan pasar sangat dimungkinkan terjadi ketika ada monopoli dan persaingan tidak sempurna dalam pasar. Karena monopoli dapat terjadi dimana satu pelaku pasar (perusahaan) mengendalikan seluruh aktivitas pasar, sehingga produsen yang bersangkutan menjadi price maker. Namun hadirnya P2P Lending justru menimbulkan beberapa perbedaan dalam Pangsa Pasar antara pelaku usaha. Berikut adalah data-data terkait pangsa pasar tersebut:

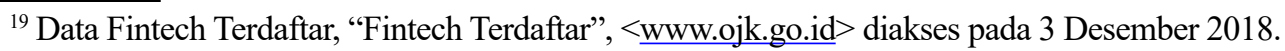


Tabel 1. Tabel Pangsa Pasar P2P Lending Terdaftar oleh OJK Periode 2017 - 2018

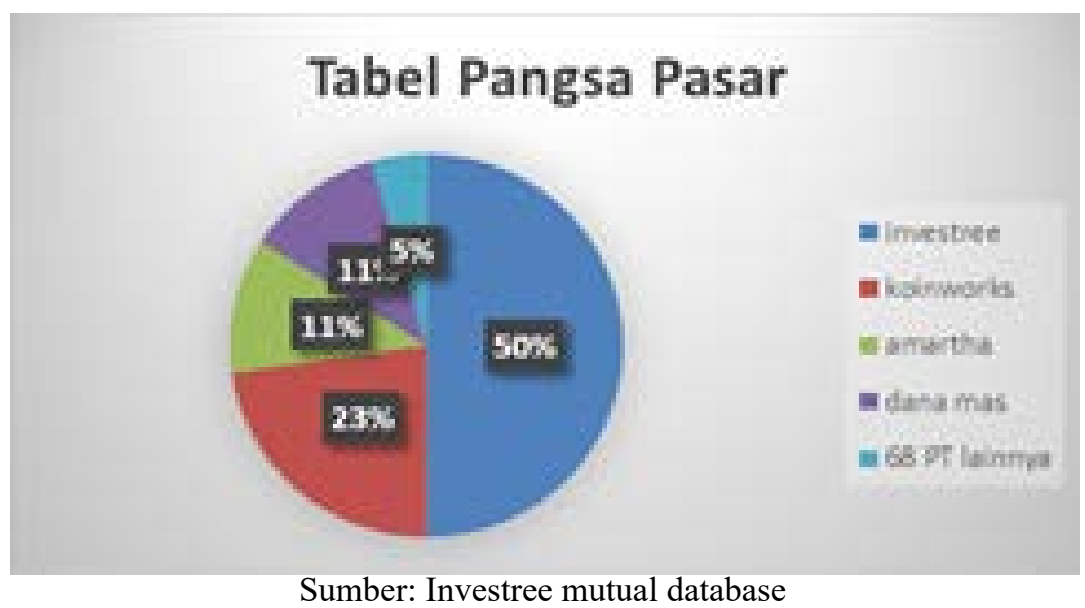

Tabel 2. ${ }^{20}$ Tabel 10 Perusahaan P2P Lending Terbaik Per- Januari 2019

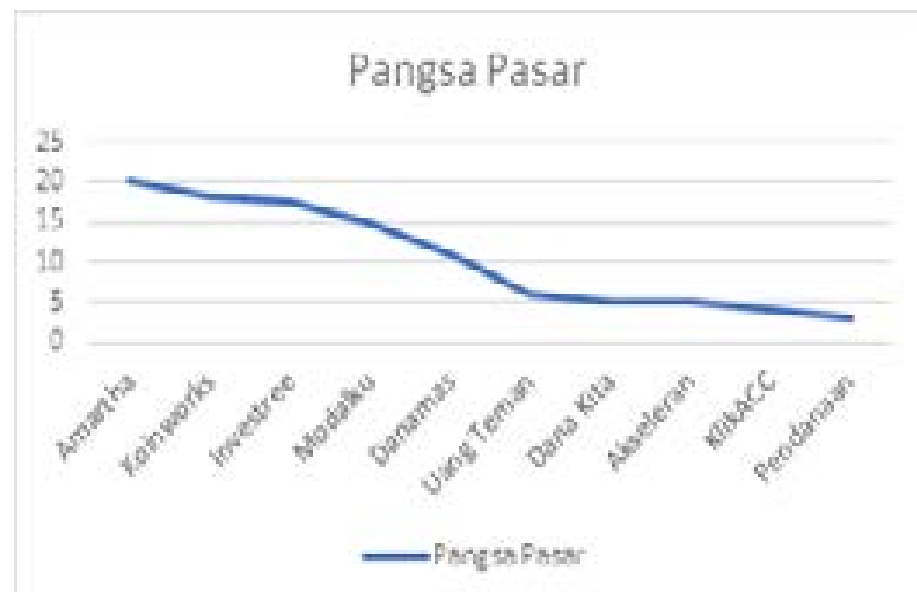

Sumber: duniafintech.com

Berdasarkan data diatas menguatkan bahwa antara P2P lending ini termasuk kedalam pasar oligopoly karena selain terpenuhinya unsur-unsur dari pasar oligopoli juga layanan P2P Lending ini mempunyai pangsa pasar atau market power yang signifikan seperti pada data diatas. Pada tabel pertama diketahui dari tahun 2017 hingga 2021 mengalami kenaikan pangsa pasar yang mulanya hanya mencapai tingkat keuntungan sampai 18 miliyar pada tahun 2021 diprediksi akan

\footnotetext{
${ }^{20}$ Dunia Fintech,“Perusahaan P2P Lending terbaik Januari 2019”, <www.duniafintech.com> ,diakses pada 8 Mei 2019.
} 
mencapai angka 38 miliyar dalam ranah pembiayaan secara digital. ${ }^{21}$ Potensi anti persaingan usaha antara layanan P2P lending satu dengan lainya akan mungkin terjadi dikemudian hari, melihat terus berkembangnya industry ini. Berdasarkan tabel kedua bahwa diketahui pertumbuhan Investree selama satu tahun berjalan setelah adanya POJK dari tahun 2017-2018, yaitu Investree sebagai pelopor P2P Lending yang dikaitkan dengan persaingan usaha yakni telah terindikasi melanggar Pasal 19 Undang-Undang Persaingan Usaha terkait penguasaan pangsa pasar. Selain itu melihat dari ketimpangan peraturan antara layanan P2P Lending dengan produk credit online system ini juga menimbulkan dampak terhadap persaingan usaha.

Kekhawatiran tersebut muncul ketika suatu lembaga P2P Lending yang bersaing dalam sebuah platform justru akan mengarah untuk mematikan pelaku usaha lainya, sehingga mewujudkan terjadinya persaingan usaha yang tidak sehat dan cenderung mengarah kepada praktik monopoli, namun termasuk kedalam kegiatan yang dilarang karena dapat menyebabkan terjadinya praktik monopoli dan atau persaingan usaha. Sebagaimana diketahui penguasaan pasar atau dengan kata lain menjadi penguasa di pasar merupakan keinginan di hampir semua pelaku usaha yang melakukan kegiatan bisnis. Karena antara penguasaan pasar dengan keuntungan memiliki korelasi yang besar untuk meraup banyak keuntungan lebih.

Penguasaan pangsa pasar diatu dalam Undang-Undang Nomor 5 tahun 1999 pada Pasal 19. Berikut adalah unsur-unsur terhadap penguasaan pangsa pasar. Unsur pertama adalah Pelaku usaha. Pelaku usaha berdasarkan Pasal 1 angka 5 UndangUndang Nomor 5 tahun 1999 adalah setiap orang perserorangan atau badan hukum atau bukan badan hukum yang didirikan dan berkedudukan di Indonesia melakukan kegiatan di Indonesia baik sendiri maupun bersama sama melalui perjanjian menyelenggarakan berbagai kegiatan usaha dalam bidang ekonomi. Dalam kasus ini PT. Investree dan Dana Instant adalah pelaku usaha terkait.

Unsur yang kedua yaitu dilarang melakukan satu kegiatan atau beberapa kegiatan, bahwa dalam unsur ini diketahui kegiatan yang dilakukan adalah

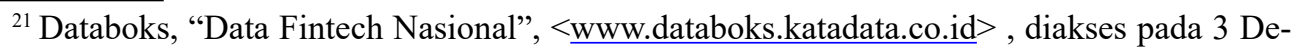
sember 2018. 
memberikan layanan pembiyaan kredit secara online. Kegiatan tersebut akan menjadi dilarang apabila menyebabkan persaingan usaha yang tidak sehat seperti mematikan pelaku usaha lainnya dimana telah dilarang didalam Undang-Undang Nomor 5 tahun 1999 dan memicu timbulnya persaingan yang tidak sehat. Tetapi unsur kedua dalam pasal ini belum terpenuhi.

Unsur ketiga adalah melakukan kegiatan usaha baik sendiri maupun bersamasama pelaku usaha lain unsur ini mempunyai arti bahwa pelaku usaha terkait yaitu PT. Investree dan Dana Instant baik bersama-sama atau melakukan usaha sejenis dengan Perusahaan lain lalu bergabung yang menyebabkan iklim pasar menjadi berubah.

Berdasarkan indikator diatas dapat diketahui telah terpenuhinya unsur pada Pasal 19 Undang-Undang Nomor 5 tahun 1999 terkait dengan penguasaan pasar adalah pelaku usaha telah melakukan penguasaan pasar. Namun penguasaan pasar yang telah memenuhi unsur atau indikator diatas berlakuhanya pada pelaku usaha yang mempunyai market power, yaitu pelaku usaha yang mempunyai pengaruh besar untuk menguasai pasar sehingga dapat menentukan harga barang dan atau jasa yang ada di pasar bersangkutan. Diketahui bahwa PT.Investree pada tahun 2017-2018 telah terdeteksi memiliki market power sebesar 50\% berdasarkan Tabel 1.

Pangsa pasar antara P2P Lending dengan Bank ini tidak dapat dikatakan sama, karena kehadiran P2P lending ini justru ada untuk menjangkau fasilitas perbankan yang tidak dapat dirasakan oleh masyarakat, karena sebagian masyarakat masih menganggap pengajuan kredit di perbankan masih rumit.

P2P Lending ini pun memiliki fungsi yang mirip dengan Bank, walaupun memiliki fungsi yang mirip dengan bank, kehadiran P2P Lending ini justru hadir untuk melengkapi peran bank dalam inklusi keuangan. Pada tahun 2015, dari 250 juta orang Indonesia, hanya 60 juta saja yang memiliki rekening bank. Dari data tersebut dapat dilihat tingkat inklusi keuangan di Indonesia bahwa hanyabeberapa orang saja yang memilih untuk menyimpan uang di Bank. Menurut data OJK, terdapat kebutuhan kredit nasional sebesar Rp1.700 triliun per tahun bagi UMKM Indonesia. ${ }^{22}$

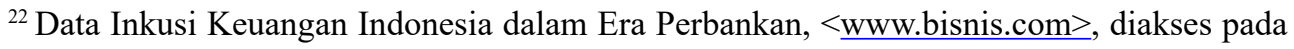
Senin 11 Maret 2019. 
Sementara, lembaga keuangan yang ada hanya dapat memenuhi Rp700 triliun dari kebutuhan tersebut, sehingga ada kekurangan pendanaan sebesar Rp1.000 triliun bagi UMKM Indonesia setiap tahun.23 Tentunya semakin banyak masyarakat yang memiliki akses keuangan, maka inklusi keuangan nasional semakin sehat dan tinggi. Dapat disimpulkan, jika akses kredit bagi UMKM masih kurang, tak hanya akan merugikan industry kecil, tetapi juga melemahkan ekonomi negara. Peran $P 2 P$ Lending hadir untuk mewadahi masyarakat yang belum mempunyai rekening di bank atau telah bankable.

Masyarakat yang belum mempunyai rekening tersebut termasuk pula UMKM yang memiliki kapasitas untuk berkembang dan butuh pendanaan. Namun masih belum mempunyai cukup rekam jejak untuk mendapat kredit dari bank. Dengan hadirnya P2P Lending akan membantu untuk mendapatkan akses keuangan dengan tanpa menggunakan jaminan seperti pada perbankan. Jaminan yang berlaku dalam pengajuan kredit di P2P Lending hanya dengan Invoice atau bukti gaji saja. P2P Lending dapat menjadi jembatan antara UMKM-UMKM yang belum mengerti institusi keuangan yang ada dengan UMKM-UMKM yang sudah bankworthy, sehingga suatu hari mereka pun menjadi bankworthy. ${ }^{24}$

Berdasarkan penjelasan tersebut dapat ditarik kesimpulan bahwa fokus P2P Lending kepada segmen UMKM yang layak kredit (creditworthy) namun belum mendapatkan kredit bank. Di sini, segmen pasar P2P Lending dan bank jelas berbeda. $^{25}$

Melihat dari perbandingan tersebut, antara P2P Lending dengan Credit Online System terdapat beberapa ketimpangan antara lain:

1. Peraturan yang menaungi layanan Credit Online System oleh Bank terkesan lebih rigid dikarenakan mengacu kepada peraturan dasar perbankan yaitu Undang-Undang Perbankan. Sedangkan peraturan yang menaungi Layanan P2P Lending hanya mengacu kepada PBI dan POJK saja.

\footnotetext{
${ }^{23}$ ibid.

${ }^{24}$ Kompas, "Perkembangan Industri Fintech Di 2017 Dalam Kaca Mata Asosiasi dan UMKM di Indonesia." <Kompas.com>, diakses pada 25 Januari 2018

${ }^{25}$ Finansialku, "Inklusi Keuangan dalam P2P Lending", <https://www.finansialku.com/ bank-fintech-p2p-lending-inklusi-keuangan> diakses pada tanggal 12 Maret 2019.
} 
2. Prinsip kehati-hatian dan Prinsip 5C dalam pemberian kredit sangat diutamakan dalam layanan Dana Instant oleh Bank Danamon karena menjadi dasar utama dalam proses pemberian kredit sesuai dengan Undang-Undang Perbankan. Berbeda dengan P2P Lending yang hanya menggunakan Prinsip 3C saja dalam pemberian kreditnya sehingga kurang menerapkan Prinsip kehati-hatian dan proses pemberian kredit menjadi cepat.

3. Prosedur pendaftaran dalam layanan dari Credit Online System dari Bank Danamon lebih kompleks karena terdapat syarat khususya itu diperuntukkan khusus kepada nasabah Bank Danamon saja. Hal ini mempunyai tujuan untuk memperkecil resiko yang ditanggung oleh Bank.

4. Prosedur pendaftaran dalam P2P Lending lebih mudah tanpa ada persyaratan khusus.

Pemberlakuan syarat yang tidak seragam, menjadikan Investree lebih mudah digunakan oleh mayarakat, karena syaratmya cukup mudah dibandingkan Dana Instan. Pelanggaran persaingan usaha dapat terjadi karena dengan pasar yang sama, Investree lebih mudah digunakan, sehingga Investree dapat dikatakan menguasai pasar didukung mudahnya persyaratan.

\section{Kesimpulan}

P2P Lending dan Credit Online System yang dimiliki oleh perbankan memiliki relevant market yang sama. Hal ini sejalan dengan persamaan karakteristik, pemenuhan semua unsur dari pasar produk yaitu segi bentuk dan sifat, fungsi, harga dan flexibilitas barang dan jasa. Dilihat pula dari segi pasar geografisnya pun untuk kedua layanan ini sama yaitu ada dalam pasar geografis yang sama yaitu berada di wilayah Indonesia.

Terdapat potensi perilaku anti persaingan usaha antara layanan P2P Lending. Potensi perilaku usaha tersebut terjadi akibat dari pemenuhan unsur - unsur dalam pasal penguasaan pangsa pasar pada Pasal 19 Undang - Undang Persaingan Usaha.

\section{Daftar Bacaan}

\section{Buku}

Arie Siswanto. Hukum Persaingan Usaha (Ghalia Indonesia 2004).

Budi Untung, Kredit Perbankan di Indonesia (Andi 2000). 
Ek O.P. Simorangkir, Seluk Beluk Bank Komersial, (Aksara Persada Indonesia Indonesia 1988).

Etty Mulyati, Kredit Perbankan Dalam Aspek Hukum dan Pengembanagan Usaha Mikro Kecil Dalam Pembangunan Perekonomian Indonesia (Refika Indatama 2015).

Hermansyah, Hukum Perbankan Nasional Indonesia (Kencana Prenada Media Grup 2011).

Mudakir Iskandarsyah, Hukum Bisnis Online Era Digital (Campustaka 2018).

Andi Fahmi Lubis, Hukum persaingan usaha teks dan konteks (KPPU 2017).

Peter Mahmud Mardjuki, Penelitian Hukum (Kencana 2005).

Purbo Onno W dan Aang Arif Wahyudi, Mengenal E-Commerce (Elex Media Komputindo 2001)

Natasya Ningrum Sirait, Ikhtisar Ketentuan Persaingan Usaha (Gramedia 2010)

Sutan Remy Syahdeni, Kebebasan Berkontrak dan Perlindungan Yang Seimbang Bagi Para Pihak Dalam Perjanjian Kredit Bank di Indonesia (Institut Bankir Indonesia 1993)

Muhammad Is Sadi, Hukum Persaingan Usaha di Indonesia, (Setara Press 2016)

Sembiring sentosa , Hukum Perbankan, (Mandar Maju 2012).

\section{Skripsi}

Airin, Perbedaan karakteristik Layanan Pinjam Meminjam Uang berbasis Teknologi Informasi (Peer to Peer Lending) dengan Perbankan, Skripsi, Program Sarjana, Universitas Airlangga, Surabaya,2017.

\section{E-book}

Renton, Peter, Understanding Peer to Peer lending, $<$ www.lendancyemy.com $>2015$

\section{Jurnal}

Komisi Pengawas Persaingan Usaha, Persaingan Sehat Sebagai Konstitusi Ekonomi , www.kppu.go.id , 2017

\section{Wawancara}


Wawancara dengan ketua Komisioner KPPU Jakarta Pusat, Universitas Narotama, 17 Juli 2018 .

Wawancara dengan Manajer Kredit Bank Danamon Surabaya, Surabaya, 9 Agustus 2018 .

Wawancara dengan Manajer Data Analyst PT. Investree, Jakarta, 9 Maret 2018

\section{Laman}

Kompas, "Perkembangan Industri Fintech Di 2017 Dalam Kaca Mata Asosiasi", $<$ https://ekonomi.kompas.com/read/2018/01/16/210000526/perkembanganindustri-fintech-di-2017-dalam-kacamata-asosiasi >, 16 Januari 2018

Kompas, "Keuntungan dan Kerugian Peer To Peer Lending," $<\underline{\text { https: } / / \text { www. }}$ kompasiana.com/graciamoudyvallentine 7708/5b4daeab5a676f1d490f6d02/ peer-to-peer-p2p-lending?page=all $>$, diakses pada 25 Februari 2019.

Sidonews, "Pertumbuhan Fintech", $<$ www.nasional.sindonews.com $>$, diakses pada 3 Desember 2018.

Republika, "Penghargaan P2p terbaik", <www.republika.co.id $>$, diakses pada 3 Desember 2018.

Data Keuangan Fintech, "Ikhtisar data keuangan fintech", <www.ojk.go.id $>$, diakses pada 3 Desember 2018.

Fintech Terdaftar, <www.ojk.go.id $>$ diakses pada 3 Desember 2018.

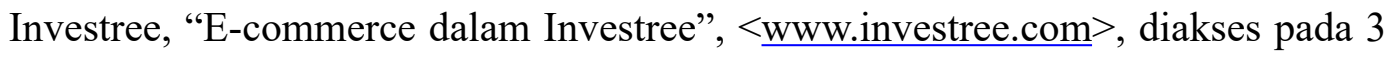
Desember 2018.

\section{Perundang-undangan}

Undang - Undang No.5 Tahun 1999 Tentang Persaingan Usaha Tentang Larangan Praktik Monopoli Dan Persaingan Usaha Tidak Sehat.

Peraturan Komisi Pengawas Persaingan Usaha No. 3 Tahun 2009 Tentang Pedoman Pasal 1 Angka 10 Tentang Pasar Bersangkutan.

Undang - Undang No.7 Tahun 1992 Tentang Perbankan.

Undang - Undang Nomor 10 Tahun 1998 Tentang Perubahan Undang - Undang Perbankan Nomor 7 Tahun 1992 Tentang Perbankan. 
Undang - Undang Nomor 5 Tahun 1999 Tentang Larangan Praktik Monopoli Dan Persaingan Usaha Tidak Sehat.

Pedoman Pasal 25 Tentang Larangan Penyalahgunaan Posisi Dominan Berdasarkan Undang-Undang No. 5 Tahun 1999 Tentang Larangan Praktek Monopoli dan Persaingan Usaha Tidak Sehat.

Peraturan Otoritas Jasa Keuangan Nomor 77/ POJK.01/2016 Tentang Layanan Pinjam Meminjam Berbasis Teknologi Informasi.

Peraturan KPPU No.3 tahun 2009 tentang Pedoman Pelaksana Pasal 1 ayat 10 No.5 tahun 1999 tentang Pasar Bersangkutan.

HOW TO CITE: Cheyzsa Mega Andhini S.P, 'Problematika Hukum Pada Peer To Peer Lending Di Indonesia Dalam Perspektif Hukum Persaingan Usaha' (2019) Vol. 2 No. 6 Jurist-Diction. 
--halaman ini sengaja dibiarkan kosong-- 